\title{
Translation as 'Bakemono': Shapeshifters of the Meiji Era (1868-1912)
}

\author{
Daniel J. Wyatt
}

\begin{abstract}
Bakemono ( 化け物) or obake (お化け) are Japanese terms for a class of $y \bar{o} k a i$ : preternatural creatures of indigenous folklore. In English they might be referred to as apparitions, phantoms, goblins, monsters, or ghosts. In the literal sense, bakemono are things that change, referring to a state of transformation or shapeshifting. Japan's period of 'bunmei kaika' (civilization and enlightenment) in the Meiji era (1868-1912) signifies the stigmatization of supernatural shapeshifters and concurrent burgeoning of bakemono of a literal kind: translation. Following the Meiji Restoration of 1868, translation of foreign literature became tantamount to the dissemination of modern thought and propelling the new governments' efforts towards the creation of a modern state. Meiji translated literature reveals the various cultural systems through which new knowledge was processed and transitioned during this period, resulting in translations which-like the traditional bakemono motif-demonstrated an adaptability that allowed texts to transform and shapeshift according to their intended purposes and readerships. Accordingly, through a diachronic investigation of a selection of supernaturally-themed texts translated from English into Japanese in the Meiji era, this paper examines the treatment of 'bakemono' both in translation and as translation.
\end{abstract}

Index Terms—Bakemono, meiji, supernatural, translation.

\section{INTRODUCTION}

The 'bakemono' (化け物) or 'shapeshifter' is a ubiquitous presence in Japanese literature. In pre-modern times, a $12^{\text {th }}$-century collection of Buddhist setsuwa tales called the Konjaku monogatari-sh $\bar{u}$ (今昔物語集) provides numerous examples of supernatural bakemono and their exploits. Often portrayed as tricksters who change shape and deceive humankind for their own enjoyment or gain, kitsune (狐; foxes), tanuki (狸; raccoon-dogs), neko (猫; cats), yacho (野 猪; wild boar), and tengu (天狗; winged demons) are among the creatures most commonly associated with shapeshifting in supernatural tales in Japan. One example from the Konjaku monogatari-sh $\bar{u}$ presents the story of a military official who rides out to the countryside seeking a woman suspected of being a fox. After finding said woman by the roadside, the man ties her to his horse and takes her to the capital where his friends are waiting to help abuse and ravage her. Encircling the woman to ensure she cannot escape, the man unties her only to discover that his friends, his surroundings, even the horse he rode in on were all an illusion of the woman's doing

Manuscript received June 5, 2017; revised September10, 2017.

D. J. W. is with the Department of Social and Cultural Studies, Kyushu University, Japan (e-mail: djwya1@gmail.com-CL025). and is left standing dumbfounded in a cemetery on the outskirts of town as the woman transforms into a fox and runs off (Takeishi 2016, 136-44) [1].

The form of the fox taken by the woman, and the form that bakemono assume when they are exposed is referred to as their 'shōtai' (正体) or 'true form'; however, the true form of the bakemono is not always known. Another example from the Konjaku monogatari-shi $\bar{u}$ tells of an unknown assailant that frequents the Jijūden Palace (仁寿殿) every night: “a certain mono (lit. 'thing') comes at midnight to steal oil from the (palace) lamps" (shinya nakagoro nani mono ka ga yattekite, ōmiakashi wo nusumidashite; 真夜なかごろ何もの かがやってきて、御燈油をぬすみだして) (Takeishi 2016, 41) [2]. The Emperor exclaims, "I want you to do something to get it to reveal its shōtai (true form)" (nantokashite, shōtai wo mitodoketai; なんとかして、正体見とどけたい) (42), and the retainer obliges, waiting in the dark for the unknown creature to appear. When he hears the creature approaching the retainer attacks it with a kick and it runs off injured. The next day he goes to investigate the room where the thing appeared and finds a trail of blood; however, "there was no other mono (thing) to be found" (hoka no mono wa nani mo nakatta; 他 のものはなにもなかった) (42). Thus, the term 'mono' (物) here (as in the compound 'bakemono' [化け物]) also functions as a general expression for supernatural creatures which do not have clear forms. As such, the shapeshifter motif in Japan's supernatural tales is both one of disguise and of discovery. Mankind may strive to unmask the identity of the bakemono, but as the two examples above reveal, 'true form' is an elusive concept. Knowing the true form, a bakemono can be referred to by its proper name, but ultimately, the form that it presents to its audience becomes the form that we come to accept and understand. The challenges posed by the manifold transformations of bakemono may be moral, ontological, and/or metaphorical, but they are etymological, as well.

Folklorist Komatsu Kazuhiko [小松和彦] (1992) notes, the themes of metamorphosis and duplicity are bound up in the connotations of the term 'bakemono': the defining act of a bakemono may be to transform (bakeru; 化ける), but its defining purpose is to deceive (bakasu; 化かす) (43) [3], and investigation into the Japanese language even further reveals how these notions of transformation and deceit have formed around the language itself. Some characters are combined with bakasu (to deceive, to bewitch) to build on or emphasize these connotations, like gomakasu (誤魔化す), which combines the characters ' $g o$ ' (誤; mistake), ' $m a$ ' (魔; 
magic/evil), and 'bakasu’ (化す; to deceive) to mean 'to cheat' or 'to hoodwink,' and 'chakasu' (茶化す), using the characters 'cha' (茶; tea) and 'bakasu' to mean 'to make fun of' or 'to turn something into a joke.' In other examples, the character for 'bake' (化け, 化ける; to change/transform) may form part of the ideogram, as in 'kusa/kusakanmuri' (+"; grass) and 'bake' (化; to transform), which becomes 'hana' (花; flower); the combination of 'kawa' (革; leather) and 'bake’ (化), becomes 'kutsu' (靴; shoe); and 'bake’ is also paired with the character 'gen’ (also ‘koto’ or ‘iu’; 言, 言う; language, words, speech, to speak) to become 'namaru' (訛

る) meaning 'dialect' or 'to speak with an accent'-thus indicating the transformation of language that occurs based on generational, regional, or environmental differences. In other variations, 'bake' becomes one character of a two- (or more) part compound. Such examples include, 'keshin' (化 身), which is comprised of the characters for 'bake' (here pronounced ' $k e$ ') and 'shin' (身; body) to mean 'avatar' or 'personification'; 'keshōhin' (化粧品), combines 'bake’ with 'shō' (粧; to adorn oneself) and ' $h i n$ ' (品; product) to mean 'makeup'; and 'kagaku' (化学), which combines 'bake' and 'gaku' (学; study) to mean 'chemistry.'

The term 'bakemono' is therefore not only relevant to the folkloric and supernatural narratives in which shapeshifting creatures run rampant and make fools of their human counterparts, but to Japanese language and all the uses, associations and constructions that connote varying aspects of 'change.' And in this sense, bakemono is also a term that becomes highly relevant to the burgeoning of translated literature in Meiji Japan as it highlights the shapeshifting nature in this period of translation itself.

\section{TRANSLATION OF BAKEMONO}

The focus of treating translated texts as 'bakemono' in this study is to present an approach that calls attention to the fluidity of translation as a trans-mutative act. The popularity of supernatural tales in the pre-Meiji era coincides with the sakoku (鎖国; closed country) policy [approx. 1639-1854] that prohibited Japanese citizens from going abroad and heavily restricted foreign trade and diplomatic relations to a few select countries, creating major restrictions on the pursuit of knowledge. The abolishment of the sakoku policy and the transition from a closed, feudal society towards a modern state with the establishment of the Meiji government in 1868, tends to be regarded as the beginnings of a shift away from pre-modern, preternatural beliefs to a focus on logic and science. More accurately, however, the Meiji period [1868-1912] represents a period of transition, as the dissemination of new knowledge can be seen to continue to circulate through and be negotiated by earlier systems of knowledge throughout the era, particularly with regards to the processing of multiple aspects of foreign culture and academic learning imported through translation. Belief in supernatural entities and phenomena were deemed as counterproductive to the Meiji governments' efforts towards becoming a modern state, and accordingly, these aspects of traditional 'uncivilized' culture-including yōkai, bakemono and all manner of preternatural beings - came to be denounced as 'meishin' (迷信; superstition) and symptoms of 'shinkeibyō' (神経病; neurological illness). Philosopher Inoue Enryō [井上円了; 1858-1919] was a key participant to this movement, establishing his “yōkaigaku” (妖怪学; lit. 'monsterology'), under the guise of which he set out to demystify all manner of supernatural entities and beliefs - the influence of which would go on to have a profound impact on Japan's kaidan (怪談; strange tale; supernatural tale; ghost story) genre in the years to come. Although this impact may be observed in a number of examples in the native literature of this era, it is perhaps most readily observable in Sanyūtei Enchō's [三遊亭 円朝; 1839-1900] ${ }^{1}$ adaptation of the traditional tale Kasane ga fuchi (累ヶ淵; Kasane Marsh) (1690) as Shinkei kasane ga fuchi (真景累ヶ淵; The True View of Kasane Marsh) (1888), resituating the appearance of the ghost in the story as a figment of the antagonist's 'shinkeibyō' (neurological illness). While Enchō expresses his ambivalence of the modern-day attitude towards kaidan tales in his preface [4] ${ }^{2}$, the title itself is in fact a play-on-words as the phonological reading of "shinkei" (i.e. Shinkei kasane ga fuchi) can mean both 'true view' (真景) and 'nerves/neuro' (神経). Not to suggest that all native supernatural tales followed the same trajectory during this period, as there are many examples of traditional kaidan retold throughout the Meiji era in the same vein as those told in the Edo [1603-1868] and other pre-Meiji eras; however, what these stories ultimately represent is the precarious status of the supernatural in a Japan striving towards modernity. The kaidan narrative, therefore, serves as a commentary on Meiji society itself, reflecting bifurcated-if not multi-furcated-(re)interpretations of the supernatural in dialogue with modern society. With a newfound importance on the translation of foreign texts and literature in this period, it was inevitable that tales of foreign ghosts and monsters, despite their reliance on supernatural themes, would make their way into the Meiji literary climate, too. And with the introduction of a foreign supernatural through the translated literature of this era, these conflicting interpretations of the supernatural elements converge with contrasting attitudes towards translation practices coupled with efforts to produce translations for a multitude of purposes and ultimately giving rise to translated texts of multiple shapes and forms. Analysis of

\footnotetext{
${ }^{1}$ An author and rakugo performer of the late Edo and early Meiji periods renowned for his adaptation of Asai Ryōi's [浅井了意; c.1612-1691] “Botan dōrō" (1666) as Kaidan botan dōrō (怪談牡丹灯籠; Tales of the Peony Lantern) (1884)

${ }^{2}$ Stating that "the advocates of civilization and enlightenment (kaika sensei-gata) hate kaidan tales as there are no such things as ghosts anymore, only illness (shinkeibyō). Shinkei kasane ga fuchi, 1888, p.1.
} 
supernaturally-themed texts translated into Japanese in this period provides insight into how Meiji translators and readers constructed meaning from the unfamiliar yet contemporary trend that was foreign literature. Accordingly, before assessing the function of translations as the shapeshifting 'bakemono' of Japan's modern era, the treatment of foreign monsters (bakemono) and the elements of a non-native supernatural that were imported and consumed through translation in this era must first be explored.

Many early translations of the Meiji era may be considered more as adaptation or 'liberal' translation rather than faithful renderings as they were often dealt with in a rather high degree of adaptive flexibility. Some interesting examples include Tsubouchi Shōyō's [ 坪 内 逍 遥; 1859-1935] translation of Shakespeare's Julius Caesar (c.1599) as Shizaru kidan: Jiyū no tachi nagori no kireaji ('A Strange Story about Caesar: The Remnant Sharpness of the Sword of Liberty') in 1884, which adopts the traditional jôruri style register; the various works of Kuroiwa Ruikō [黒岩涙香; 1862-1920] who often kept original settings but adapted the characters to bring them closer to the Japanese reader (e.g. Edmond Dantès in Dumas' The Count of Monte Cristo becomes “Dantomotarō” (團友太郎) in Kuroiwa’s Gankutsuō

(玈窟王; ‘The Cave King’) (1901)); Keien’s (圭円子) adaptation of Thackeray's Bluebeard's Ghost (1843) as “Ao yūrei” (青幽霊; 'The Blue Ghost') in 1891, that sees Bluebeard transformed into the ghost of a Japanese army general who dies on the battlefield and returns to haunt his wife; and Aeba Kōson's [饗庭筌村; 1855-1922] adaptation of Dickens’ A Christmas Carol as “Kagebōshi” (影法師; 'Silhouettes') in 1888, depicting Saheiji's (佐平次; Scrooge’s) visit by Matabei’s (又兵衛; Marley’s) ghost on new year's day (instead of the original Christmas day setting).

However, examples that are particularly interesting to this study f'or the treatment of bakemono in the ontological sense includes Kanagaki Robun's [仮名垣魯文; 1829-1894] translation of Shakespeare's Hamlet (c.1600-1601) as “Seiyō kabuki hamuretto” (西洋歌舞伎葉武列土; “Western Kabuki Hamlet') in 1875 and subsequent retranslation as "Hamuretto yamato nishikie” (葉武列土倭錦絵; “The Story of Hamlet in Japanese Color Woodblock Print') in the Tokyo e-iri shimbun newspaper in 1886; Aeba Kōson's translation of Edgar Allan Poe's “The Black Cat” (1843) as "Seiyō kaidan kuroneko" (西洋怪談 黒猫; 'Western Kaidan: The Black Cat') in the Yomiuri shimbun newspaper, 1887; Shibue Tamotsu's [渋江 保; 1857-1930] translation of Jacob and Wilhelm Grimm’s Grimm's Fairy Tales (Kinder- und Hausmärchen) (1812) as Seiyō yōkai kidan: Shōgaku kōwa zairyō (西洋妖怪奇談 小学

講話材料; 'Strange Western Yōkai Tales: Elementary School Teaching Materials') in 1891; and Osada Shūtō's [長田秋濤; 1871-1915] translation of Poe's The Murders in the Rue Morgue (1841) as “Shōjōkai” (猩々怪; lit. 'Supernatural Orangutan') in 1899.

The above texts have been chosen for analysis here because they provide a broad spectrum of non-Japanese supernatural phenomena that were interpreted in culturally specific ways when translated into Japanese, but as is explicated in the second half of this study, their subsequent re-translations concern not only shifts of language or culture but genre and register as well.

\section{A. Shakespeare: King Hamlet's Ghost as 'Kori'}

In 1875, Kanagaki Robun began to adapt Hamlet into "Seiyō kabuki hamuretto" for the Hiragana e-iri shimbun newspaper. The adaptation, left unfinished, was completed a decade later under the title of Hamuretto yamato nishikie (葉 武列土倭錦絵; The Story of Hamlet in Japanese Color Woodblock Print), serialized in the Tokyo e-iri shimbun newspaper from October 6-November 16, 1886. Kanagaki states his intent to adapt the story in kabuki-style in his preface, transposing the setting to medieval Japan with character names loosely based on their original counterparts (Hamlet, here, thus becomes Hamura Maru [葉叢丸]) [5]. While these undertakings are clearly evidenced throughout the story with visual clues and illustrations, most curious to this study is Hamura Maru's (Hamlet's) encounter with his father's ghost (Fig. 1). In the illustration Hamura's father, the former king, is surrounded by a ghostly light, called a 'hitodama' (人魂; a floating light that either represents a supernatural being or the soul of the deceased), and although the ghost is referred to as such (that is, as "senō no bōrei” [先 王の亡霊] or “the ghost of the late king”) in the character list at the beginning of the piece (Kanagaki 1996, 8), his first appearance in Act I Scene 3 comes with great caution from Hamura's subordinates who warn him that it is not the late king, only a "kori" (狐狸; an ambiguous term that connotes either a fox or a tanuki with the ability to shapeshift) impersonating him. The scene begins with Hamura receiving reports of sightings of his father's “mitama” (御霊; spirit), but is warned to heed caution as it must be "kori no shiwaza" (狐 狸の仕業; the work of a kori) and “kori no henge” (狐狸の変 化; a shapeshifting kori) (Kanagaki, 22). Nevertheless, Hamura Maru goes to investigate. The text states:

The moon in the clouded sky peeked through the leaves of the trees when out of the mist appeared the figure of the late king on horseback. Hamura's face was one of concern, "As we have heard, it is the figure of my father, but it may be the transformation of a kori taking advantage of the sadness of his passing, let us catch it and make it reveal its true form," and as he advanced on it, hand readied on the hilt of the sword fastened around his waist, the being emitted a flickering light and disappeared. ${ }^{3}$ (Kanagaki 1996, 22).

\footnotetext{
${ }^{3}$ All translations herein are the author's own unless otherwise stated. Source Text: 「...葉越の月の雲隠れ霧立こむる眼前に茫然としてあら はれたまふ亡き兼頼の馬上の姿葉むら丸は吃となり「聞しに違はぬ父 君の御姿と八見たてまつれど父の死別の泣みに附入る狐狸の变化な らむイデひつ捉へて生体をと佩刀に手をかけ詰よすれバー進一退か げらふのあるかと見れバぱつと消え」
} 


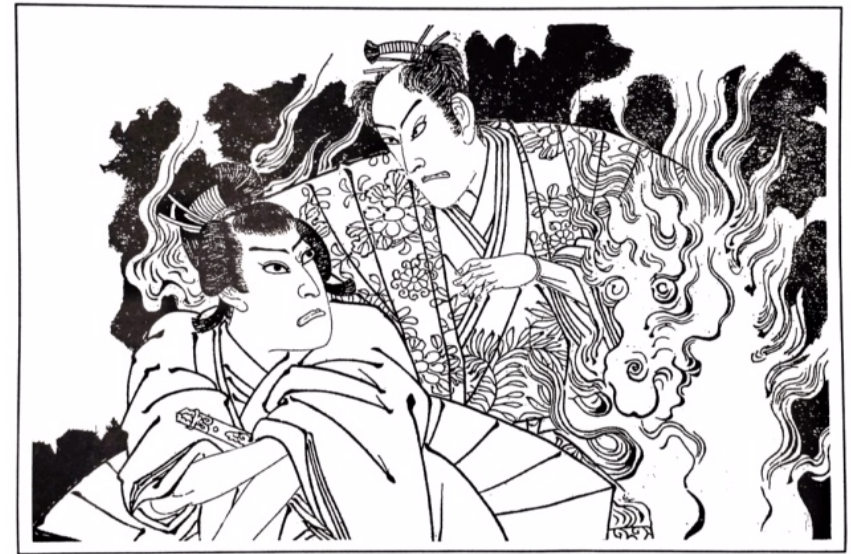

Fig.1. Hamura Maru encounters his father’s ghost (Kanagaki, 24).

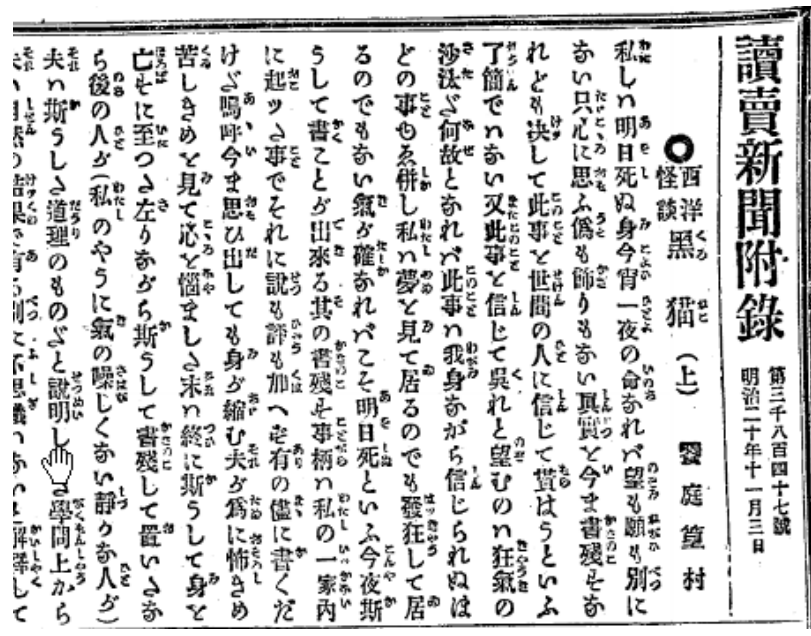

Fig. 2. "Seiyō Kaidan: Kuroneko” in Yomiuri Shimbun (1887).

\section{B. Edgar Allan Poe: Black Cat as 'Bakeneko',}

“The Black Cat" is a murder/confession tale involving themes of madness, animal cruelty, and psychological guilt, and it became the first of Edgar Allan Poe's stories to appear in Japanese, translated by Aeba Kōson as "Seiyō Kaidan: Kuroneko” (西洋怪談 黒猫; “Western Kaidan: The Black Cat') and serialized in the Yomiuri Shimbun newspaper on November 3 and November 9, 1887 (Fig. 2). The narrator of the story is an animal lover but is also haunted by his increasing alcoholism and feelings of perverseness. He adopts a black cat called Pluto which he cares for deeply until one day he decides to gouge out one of its eyes from the socket. Despite feelings of regret for his actions, the narrator's anger towards Pluto escalates further and he hangs the cat in the garden-an act which is proceeded by the mysterious burning down of the narrator's home. However, when a second black cat suddenly appears one day-missing the same eye as his previous cat, Pluto, and almost completely identical except for one white patch of fur on its chest-he decides to adopt this cat, too. The narrator is eventually consumed by anger once more and picking up an axe to end the life of the second cat he swings at the creature but misses, accidentally killing his wife instead. He decides to hide his wife's body inside the wall of the cellar, and when

\footnotetext{
${ }^{4}$ This segment appears in D.J. Wyatt, “Towards a Transcultural Supernatural: Edgar Allan Poe's “The Black Cat” and Western Gothic Tales in Japan’s Meiji Era” (submitted for publication).
}

the cat doesn't return either-believed to have run away- the narrator becomes elated with feelings of relief and great joy. Police officers come to investigate the wife's disappearance, even searching the cellar, but to no avail. It is only when they go to leave that a howling from within the walls rouses suspicions, and upon tearing it down, it is revealed that the narrator unknowingly walled the cat in with the wife's decomposing corpse, ultimately exacting his own demise - the narrator is charged with the crime and sentenced to death (Poe 2014, 207-13) [6].

Tzvetan Todorov (1973) situates “The Black Cat” within the generic category of "pure fantastic" for the ambiguous nature of the tale and the ultimate unknowing of whether the supernatural in the story is in fact supernatural or whether it can be explained naturally [7]. However, through intertextual markers, Aeba Kōson reinterprets the cat of the tale as a creature akin to the traditional 'bakeneko' ( 化け猫; shapeshifting cat) and thereby repositions the story within the Japanese kaidan genre, albeit with a "seiyō" (Western) twist. His reinterpretation of the tale is most evident in the description of the protagonist's encounter with the cat of the title. The ST (source text) reads:

[A] remarkably large and beautiful animal, entirely black, and sagacious to an astonishing degree. In speaking of his intelligence, my wife, who at heart was not a little tinctured with superstition, made frequent allusion to the ancient popular notion, which regarded all black cats as witches in disguise.

(Poe 2014, 207)

Aeba's TT (target text) in the November 3 edition of the Yomiuri shimbun, however, reads:

A truly beautiful cat with pitch-black fur like velvet and eyes like golden bells, and also surprisingly smart, to which my wife was a little suspicious. It has long been said that black cats are the transfigured form taken by magic-wielding old women after all. ${ }^{5}$

(Aeba 1887) [8]

Although not immediately apparent to non-Japanese readers, the allusion to the Japanese 'bakeneko' or 'shapeshifting cat' becomes obvious through a comparative reading of traditional kabuki stories, kōdan (storytelling narratives), and kaidan tales of bakeneko throughout Japanese history. These include the kabuki tales by Kawatake Shinshichi [河竹新七 (三世); 1842-1901], Segawa Jokō [瀬川 如泉 (三世); 1806-1881], and Kawatake Mokuami [河竹黙阿 弥; 1816-1893], kōdan tales by Momokawa Joen [桃川如燕; 1832-1898], as well as numerous 'real accounts' (jitsurokumono; 実録物) and picture books depicting stories and illustrations of fear-inducing felines throughout the Edo and Meiji eras. Of particular interest to this study, though, is

\footnotetext{
$5 「$ 至りて美しい猫で毛は真黒で天黛緁の如く眼は黄金の鈴に似て かしこきことは驚くほどゆ㤩妻は是に付いて少し迷ひが有ツた。夫 は昔から黒猫は魔法遣ひの老婆の形を變へたものだといふ事がある ので」 Emphasis added by the author.
} 
Momokawa Joen’s Takayagura rikishi kyūmyōden (高櫓力士 旧猫伝; 'Old Cat Tales - The Sumo Wrestler and the Watchtower') (1885), the finale of which portrays the bakeneko of the story facing off against sumo and samurai in a battle to the death (Fig. 3). In the final scenes, sumo wrestler, Onogawa, catches a glimpse of the cat that has been terrorizing the village:

Looking closely, (he could see that) the creature was entirely black, like it was cloaked in a beautiful velvet, it's tail split in two, it's eyes shone golden, it's very shape was that of a tiger. So this is the form that the aged cat takes (he thought). ${ }^{6}$

(Momokawa 1885, 97) [9]

In later scenes the bakeneko of the story is again described with "pitch-black (fur) that shimmered in the light like velvet” (眞黑に變じ光りを生じて天䳔絨の如く) and with “eyes that shone like golden bells” (眼は黄金の鈴に似て月無 空に明星が照輝くが如く) (Momokawa 1885, 101). Through a comparison of Kōson's “Seiyō Kaidan: Kuroneko" and Momokawa's Takayagura rikishi kyūmyōden, it becomes immediately apparent that Kōson's interpretation of the text is influenced by a much larger cultural context. The intertextual references in Kōson's translation stress what John Stephens (1992) defines as "the production of meaning from the interrelationships between audience, text, other texts, and the socio-cultural determinations of significance" (84) [10]. While the various intertextual elements of Kōson's translation have become largely undiscernible to the modern-day reader, an historical reading in the Meiji context of the translation reveals the intimate relationship between translation and traditional culture in the processing of new knowledge at this point in Japanese history.

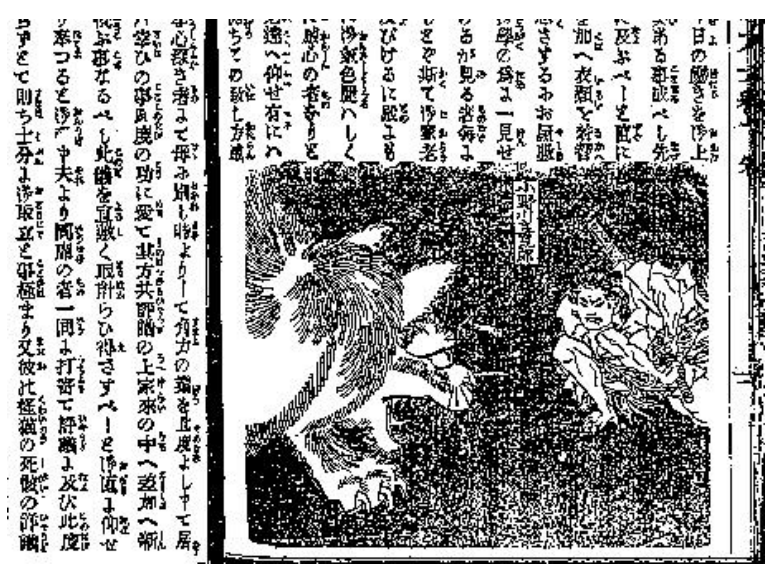

Fig. 3. Bakeneko and Sumo face-off in Takayagura rikishi kyūmyōden (Momokawa 1885, 103).

\section{Grimm Brothers: The Seven Swabians and 'Kappa'}

"The Seven Swabians" (Die Sieben Schwaben) is a German fairy tale collected by The Grimm brothers in the

\footnotetext{
6「瞳と定めて䙼き見れば惣身一体眞黑にして其美麗き事天黛䄉の 如く尾は二股に裂廣がり眼は金色に光り輝き其形容宛然畫ける虎の 如く是ぞ全く猫の年經し者と見定め」Emphasis and items in parentheses added by the author.
}

second volume edition of their Kinder- und Hausmärchen (1857). ${ }^{7}$ The story tells of seven Swabians ${ }^{8}$ crossing the countryside when they come across the Moselle river. Not knowing how to cross they call out to a man working on the other side, but the man not hearing them over the distance replies in his native language, "What, what?" The Swabians, mistaking his words for "Wade, wade across," think it's safe to cross. The first Swabian jumps in and immediately drowns. His hat however blows across to the opposite shore when a frog appears beside it and croaks, "Wat, wat, wat." The remaining six think that the first Swabian is calling them across and the story ends, "So they all jumped into the water together in a great hurry, and were drowned, and thus one frog took the lives of all six of them, and not one of the Swabian allies ever reached home again” [11]. Shibue Tamotsu's translation of the tale appears in his Seiyō yōkai kidan: Shōgaku kōwa zairyō (西洋妖怪奇談 小学講話材料; 'Strange Western Yōkai Tales: Elementary School Teaching Materials') ${ }^{9}$ in 1891 as the $38^{\text {th }}$ tale in his collection, “Shichimei no Sūebiajin” (七名のスウエビア人; The Seven Swabians) (Fig. 4) [14].

Shibue's translation of the tale, however, ends as follows:

Only the hat he was wearing resurfaced, bumping into a frog which croaked in a fright, "Wat, wat, wat" - in Japanese it would read "Gaa, gaa, gaa" - and the six on the bank mistaking this as a call to "wade, wade, wade," said,

Listen, isn't that Shultz calling us across? If Shultz could make it across, then we can too.

Regretfully, the six lined up and jumped in the river together, and in the end, falling victim to kappa? After that, they were never seen again. ${ }^{10}$

(Shibue 1891, 252)

Shibue has the Swabians falling victim to "kappa" 11 (kappa no ejiki to nari; 河童の餌食となり), instead of the frog claiming their lives as in the original. At the end of the tale, translator Shibue goes on to state that he added kappa into the story as there are no other "kaidan-like elements"

\footnotetext{
${ }^{7}$ Referenced 'KHM 119'.

${ }^{8}$ 'Swabian' refers to a native or inhabitant of the medieval German duchy of Swabia.

${ }^{9}$ A collection of 40 translated tales including 37 from Grimms' Fairy Tales, the story of "Ali Baba and the Forty Thieves" from Arabian Nights, and two other tales according to M. Kawato, Y. Noguchi, and T. Sakakibara (2000, pp. 132-33) [12]. However, as H. Nishiguchi has indicated, 38 of these tales are translations of Grimms' Fairy Tales and the remaining 2 stories are from Arabian Nights. See: Nishiguchi 2013 [13].

$10 「$ 左れどその被りし帽のみは水上に浮ひてー匹の蛙に衝突しか ば、蛙は驚きて「ウェット々々々」我が邦語に所訳「ガー々々」と叫 ひしに、岸上の六人はシユレツが渡れ々々と叫ひしと誤想へ、聞かれ よ、シユレツが我れ々々を招くでは御座らぬか? ?シユレッスラ渡り超 に得るものを、我れ々々争で渡り得ざらん。閔然や六人の者は一同に 肩を比べて河中に飛込みしが、遂に河童の餌食となりしか？その後更 に行衛知れざりしといふ」

${ }^{11}$ Kappa (河童) are another creature of traditional folklore, believed to inhabit the ponds and rivers of Japan.
} 
(“kaidan-rashiki kasho”) in the story (Shibue 1891, 252). ${ }^{12}$

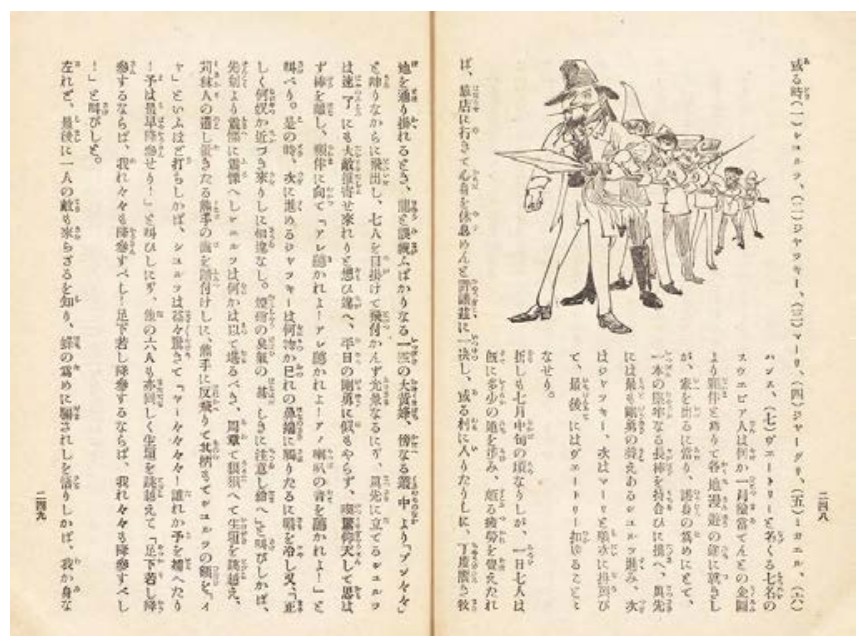

Fig. 4. "Shichimei no Sūebiajin” (Shibue 1891, 248).

\section{Edgar Allan Poe: Orangutan as 'Shōjō'}

Edgar Allan Poe's The Murders in the Rue Morgue (1841) is often accredited as the first modern detective story and concerns the solving of a murder carried out under seemingly impossible circumstances, by an unknown assailant of exceeding strength and superhuman ability. Eventually the murderer is revealed to be none other than an orangutan that had escaped its enclosure. The first translation appeared in Japan by way of Aeba Kōson ${ }^{13}$ in December 1887-shortly after his translation of "The Black Cat". The story was translated again in 1899 by Osada Shūtō as "Shōjōkai" (猩々 怪), this time the translator re-positioning the tale as a 'kaidan', stating in the foreword: "This kaidan was told to me during my time in Paris...” (此怪談は予が嘗て巴里に居つた 時分、人から聞いた話で) (Osada 1899, 118) [15]. While the story certainly displays elements of the uncanny, Osada's decision to reposition the story as a kaidan tale would seem unconventional were it not for the word 'shōjō' (as in the title "Shōjōkai" [猩々怪]) in the then Meiji context. Prior to the Meiji period, shōjō existed purely as a creature of myth, and it was only through the import of Western knowledge, particularly through the translations of biological and scientific texts and encyclopedias, that the shōjō's 'shōtai' (true form) as an orangutan was eventually revealed.

Although originating in China, the preternatural yōkai shōjō is a popular motif in Japanese folktales and Noh plays of pre-modern Japanese history. Early documentation of the shōjō and its Chinese origins can be found in a translation of the 'Illustrated Sino-Japanese Encyclopedia', Wakan sansai zue (和漢三才図会), compiled by Terajima Ryōan (寺島良安) and first published in 1712 (Fig. 5). Stories and imagery of the shōjō as a monkey-like creature that liked to drink alcohol and had the ability to speak continued to flourish throughout the Meiji era, particularly in the cultural sphere of Japanese Noh and folklore where the shōjō also came to be known as a

$12 「$ 本文只末尾に河童の事を載せたるのみにて、他に怪談らしき 箇所なし」

${ }^{13}$ Under the pen name Takenoya Shujin (竹の舎主人). red-haired water-dweller that brought good fortune-while some other interpretations introduced the theme of capturing the shōjō for personal gain as well.

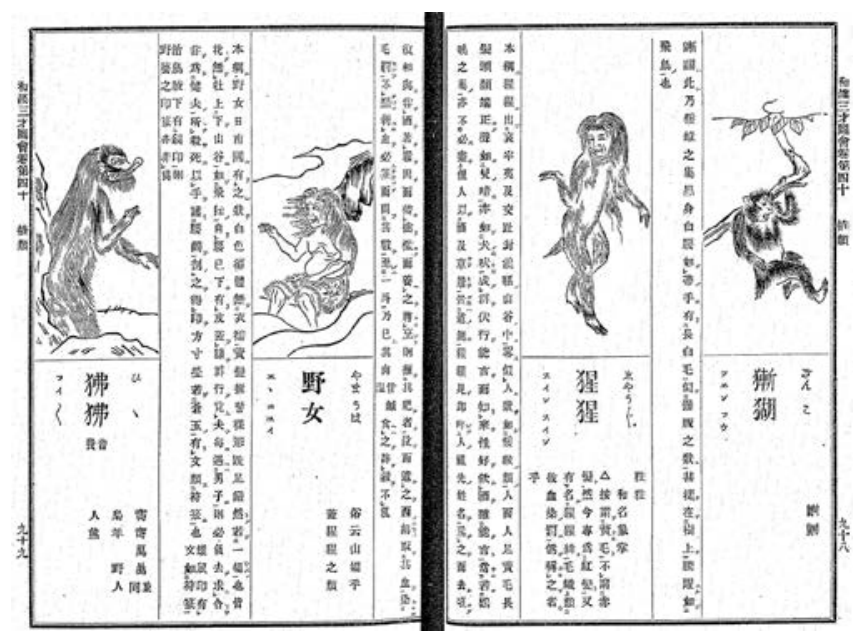

Fig. 5. The 'shōjō' (second from right) in Wakan sansai zue $(1888,98)$ [16].

With the influx of translations of scientific texts from the beginning of the Meiji era onwards, the knowledge of a modern day creature unknown to the majority of Meiji society - the orangutan —also came to be referred to be the name 'shōjō', and explication of the shōjō as an orangutan can be found in translated texts from as early as $1875 .{ }^{14}$ However, many examples of the traditional imagery of the preternatural shōjō continue to circulate in various forms of printed media throughout the era, particularly the years surrounding Osada's translation, such as "Shōjō" (猩々) in Tsukioka Kōgyo’s [月岡耕漁] Nōgaku zue (能樂圖繪; Noh studies: Illustrated) in 1898, Kyoiki mukashibanashi: Shōjō no hanashi (教育昔話 猖々の話; Educational Old Tales: Story of the Shōjō) by Honekawa Dojin (骨川道人) in 1899, and “Shōjō" (猖々) in Nōgaku zue (能楽図絵; Noh Studies Illustrated) by Kawanabe Yutaka (河鍋豊) also in 1899.

The four translations provided above barely scratch the surface of the multitude of ways in which foreign monsters and supernatural beings were processed through traditional cultural knowledge of native Japanese bakemono — a strategy that might also be viewed in the field of Translation Studies today as 'cultural equivalence'. ${ }^{15}$ The various socio-cultural contexts within which the connection between traditional culture, bakemono and modern knowledge was constructed in this period and how representations of the foreign supernatural transitioned through multiple knowledge systems, not only lent to the construction of new meanings and understandings of foreign literature, but in part, revalidated the position of kaidan literature and traditional culture in modern society as well.

\footnotetext{
${ }^{14}$ For example, in Y, Tanaka, Dōbutsu kunmō: Shohen (honyurui) (動物 訓蒙 初編 [哺乳類]; 'Guide to Animals: Volume 1 [Mammals]'), Tokyo: Hakubunkan, 1875, p.6.

${ }^{15}$ A translation method that involves "replacing a culture-specific item or expression with a target language item which does not have the same propositional meaning” (Baker 1992, 30) [17].
} 


\section{TRANSLATION AS BAKEMONO}

This study thus far has focused on the treatment of foreign literature translated from English into Japanese in the Meiji era, demonstrating how Western ghosts, fairytales, and fear inducing creatures were interpreted through systems of traditional knowledge in a way that foregrounded their associations with familiar supernatural tales and native folklore. Analysis herein, however, shall focus on the subsequent re-translations of the four examples to highlight the translated literature of this period as a non-static entity facilitating multiple interpretations and sites of meaning production. Investigation into how the various ghosts, monsters, and supernatural creatures depicted in the examples above continued to develop and evolve through their numerous retellings and re-translations throughout the Meiji period is certainly worthy of future study. Nevertheless, the avenues through which translations appeared and reappeared in multiple shapes and forms reveals another telling aspect to this study and the nature of translation in the Meiji period as the shapeshifting 'bakemono' of the modern era.

As shapeshifters, bakemono have the ability to adapt to their surroundings and appear in a form they determine most effective or relevant to their audience. For translators like Kanagaki Robun, Aeba Kōson, Shibue Tamotsu, and Osada Shūtō, their interpretations of the supernatural elements in their stories hark back to various traditions, most notably to kabuki tales, kōdan storytelling, kaidan and native folklore. Their renderings also invite the Meiji reader to draw their own intertextual associations to the texts in ways that perhaps enhance the entertainment factor and make the stories more familiar to the respective target audiences. 'Translation,' when broken down into its morphemes, denotes both 'crossing' (trans-) and 'movement' (-latio), and accordingly, a border-crossing or a movement of meaning that traverses national and linguistic barriers posits a suitable defintion of the act of translation. Border crossing is certainly evident in texts that were translated from English and other European languages in late $19^{\text {th }}$ and early $20^{\text {th }}$ century Japan (or any translation, at anytime, anywhere for that matter); however, Meiji translations not only reflect a transition of language but, in some cases, a complete mutation of meaning that could shape and adapt to specific readerships in accordance with shifting socio-cultural currents and evolving ideologies of the time. Thus, when observing the multiple appearances of a single text over the 45-year span of the Meiji era like Hamlet (of which there are at least 35 confirmed examples [18]) or Edgar Allan Poe's “The Black Cat” (of which there are 8 confirmed examples [19]), the process through which (re-)translations take on new meanings, not only based on their content and how they are translated but why and for whom they are translated, becomes at once both apparent and mystifying. Translation, therefore, not only provided a means for bakemono and monstrous creatures to manifest and shapeshift in the imaginations of the translators and the readers of this period; translation itself became the bakemono.

Building on this theory of 'translation as bakemono', a cultural analysis of the supernatural creatures and a diachronic investigation into the retranslations of the four texts in the examples above is examined herein.

\section{A. Hamlet}

The Meiji Restoration abruptly brought Western civilization to Japan in various fields including politics, economics, education, religion, and literature. One of the greatest influences in the field of literature was the introduction of William Shakespeare. The works of Shakespeare appeared in various forms: translations, partial translations, and adaptations including those which recreated the original characters with Japanese names and personas and repositioned the original settings into the Japanese archipelago. For example, Romeo and Juliet (c.1595-1596) translated by Kawashima Keizō [河島敬蔵; 1859-1935] as “Shunjō ukiyo no yume” (春情浮世之夢; ‘Dreams of a Floating Spring’) (1885), and again by Kinoshita Shinzaburō [木下新三郎; details unknown] as “Seiyō musume setsuyo: Adamusubi fushigi no enishi” (西洋娘節用 仇結奇之赤縄; 'Writings on Western Girls: A Peculiar Marriage Between Rivals) (1887); Julius Caesar (c.1599) translated as by Tsubouchi Shōyō as “Jiyū no tachi nagori no kireaji” (自由太

刀余波鋭鋒; 'A Strange Story about Caesar: The Remnant Sharpness of the Sword of Liberty') (1884), also translated by Kawashima Keizō and Komiyama Tenkō [小宮山天香; 1855-1930] as “Roma seisui kagami” (羅馬盛衰鑑; ‘The Mirror of the Rise and Fall of Rome') (1886); and The Merchant of Venice (c.1596-1597) translated by Inoue Tsutomu [井上勤; 1850-1928] as “Jinniku shichiire saiban” (人肉質入裁判; ‘The Trial for the Pawning of Human Flesh’) (1883). The earliest of Shakespeare's translations, Kanagaki Robun's "Hamuretto" (Hamlet) in 1875-later re-published in 1886 - represents only a single translation of the numerous "Hamlets" that appeared over the 45-year period of the Meiji era (including original translations, adaptations, re-translations, and reproductions of original text). In the introduction (Daijo; 大序) of Kanagaki's translation is the subheading “A reformed Japanese play-A period kyōgen (kabuki play) from England” (Nihon no kairyō shibai ha, igirisu no jidai kyōgen; 日本の改良劇は、英国の時代狂言) (Kanagaki 1996, 10). The term 'reformed' (kairyō) was a key word to the Meiji era and its use was in no way unique to translations and adaptations of foreign literature. Translations of works relating to politics, education, administration and the military certainly occupied a central position in Meiji literature, particularly in the early years of the era, and from the mid-1870s onwards, this fascination began to extend to 'seishin bunka' (精神文化) or 'moral culture', that is, culture born through the workings of the human mind (including fields of science, religion, philosophy, religion, and art) and a great number of texts such as Hamlet were translated and manipulated extensively throughout this period in Japanese history to serve these various reforms.

Accordingly, Shakepeare's Hamlet appeared not only in newspapers (such as Kanagaki's “Hamuretto” above, or those like “Shunshō yobanashi” (春宵夜話; ‘Spring Evening Tale’) translated by Fujita Mokichi [藤田茂吉; 1852-1892] 
and serialized in the Yūbin hōchi shimbun (郵便報知新聞) newspaper from June 2-21, 1883); but also in women’s educational magazines (such as “Shōtai Hamuretto” (正体は むれッと; The True Form Hamlet) translated by Yamada Bimyō [山田美妙; 1868-1910] and serialized in the May and September editions of Iratsume (以良都女) in 1888; and “Higeki tama mayō tsuki no yaiba ichimei katsura gorō” (悲 劇魂迷月中刃一名・桂吾良) translated by Iwano Hōmei [岩野 泡鳴; 1873-1920] and serialized in Jogaku zasshi (女学雑誌; 'Women’s Studies Magazine’) from August-October, 1894); English study magazines (such as "Saō gikyoku: Hamuretto shōkai” (沙翁戯曲ハムレット詳解; ‘Shakespeare’s Plays: Guide to Hamlet') translated by Murata Yuji [村田祐治; 1863-1944] in the March edition (to volume 56) of Nihon eigaku zasshi (日本英学雑誌; 'English Studies Japan Magazine') in 1892; and, “Hamuretto” translated by Harunoya Shujin (春廼屋主人) ${ }^{16}$ for the August edition of Gaikokugo zasshi (外国語雑誌; 'Foreign Language Studies Magazine') in 1897); Children's literature magazines (such as “Hamuretto no tan” (ハムレットの譚; “The Tale of Hamlet') in Shōnen no tomo (少年の友; 'Young Boys' Companion'), August, 1891; and, "Denmāku ōji hamuretto" (丁抹王子ハムレット; ‘Danish Prince Hamlet’) in Shōnen bunshū (少年文集; 'Young Boys' Anthology'), February, 1899); as well as a number of general literary magazines, kabuki publications, and novellas-including one that might provide further insight into the relationship between translation and traditional knowledge in the Meiji era, published in May 1901 as Yōkai (妖怪) and referring to the ghost of King Hamlet as a "yōkai" and a "bakemono." In this period we can also find the works of a single translator appearing across multiple publications, like Tsubouchi Shōyō's Hamlet appearing as "Denmaruku no ōji: Hamuretsuto monogatari” (甸国皇子班列多物語; ‘Prince of Denmark: The Tale of Hamlet') in Chuō gakujutsu zasshi (中 央学術雑誌; 'Central Academic Journal') in July 1885, “Denmaruku no ōji: Hamuretto no higeki” (デンマルクの皇 子ハムレットの悲劇; 'Prince of Denmark: The Tragedy of Hamlet') in Waseda bungaku (早稲田文学; 'Waseda Literature') from March to May 1896, “Saō saku “Hamuretto” no issetsu” (沙翁作「ハムレット」のー節; 'Works of Shakespeare: Passages from Hamlet') in Gaikokugo zasshi (外国語雑誌) in August 1897, and “Hamuretto” (ハムレット) in Waseda Bungaku from June to October, 1907.

Yamada Bimyō's translation of Hamlet as "Shōtai Hamuretto” (正体はむれッと; The True Form Hamlet) appearing in the $11^{\text {th }}$ edition of Iratsume (以良都女) on May

\footnotetext{
${ }^{16}$ Pen name of Tsubouchi Shōyō [坪内逍遥].
}

20, 1888, appears alongside various ‘lifestyle’ related articles such as “Kodomo no sodatekata” (小供の育て方; 'how to raise children’), “Jinkō no kikei” (人工の奇形; ‘artificial birth defects'), “Kyūbyō no teate” (急病の手当て; ‘treating sudden illnesses’), “Ifuku haoriji/Sōshokuhin” (衣服羽織地・装飾品; 'haori coat materials and decorations'), and "Keshōyaku eramikata” (化粧薬えらみ方; 'how to choose cosmetics'). Accordingly, each of these translations adopts different registers and translation strategies, and published in different platforms, therefore suggesting an array of different target audiences and potential readings.

\section{B. "The Black Cat"}

Although not to the extent of Hamlet, several translations of "The Black Cat" also surfaced at different times throughout the Meiji era. Following Aeba Kōson's “Seiyō kaidan: Kuroneko” in 1887 was Uchida Rōan’s [内田魯庵; 1868-1929] “Kuroneko” (黒猫) in Chōryūkōgo (鳥留好語) 1893; Sakurai Ōson's [櫻井鴎村; 1872-1929] “The Black Cat” in Eibun shinshi: The Student (英文新誌: The Student), July-December, 1904; Kikuzuki’s [掬月生; details unknown] “Kuroneko” (黒猫) in Shōnen (少年; 'Young Boys'), May-June, 1905; Hata Kakō’s [畑荷香; details unknown] “Kuroneko monogatari” (黒猫物語; “The Tale of the Black Cat') in Shinko bunrin (新古文林; lit. 'Forest of Old and New Literature'), January, 1907; Honma Hisashirō's [本間久四郎; details unknown] “Kuroneko monogatari” (黒猫物語; “The Tale of the Black Cat') Meicho shinyaku (名著新訳; 'New Translations of Famous Works'), November, 1907; Kita Tōichi’s [紀太藤一; 1879-1936] “The Black Cat: Kuroneko” (The Black Cat: 黒猫) in Eigo no Nippon: The Nippon (英語 の日本: The Nippon; lit. 'English of Japan: The Japan'), June-December, 1909; and Hiratsuka Raichō’s [平塚らいて う; 1886-1971] “Kuroneko” (黒猫) in Seitō (青鞜; “Blue Stockings'), December, 1911.

Interestingly, the first seven of Poe's translations in Japan-Aeba Kōson’s “Seiyō kaidan: Kuroneko” (1887), "Rū morugu no hitogoroshi" ("The Murderer of the Rue Morgue'=The Murders in the Rue Morgue) (1887), and “Megane” (目鏡; The Spectacles) (Yomiuri Shimbun, January 3-20, 1888), as well as “Karasu” (鴉; The Raven) translated by Watanabe Matsushige [渡辺松茂; details unknown] (Nyu nashonaru dai-go dokuhon chokuyaku; ニューナショナル第 五読本直訳; ‘New National Fifth Reader: Direct Translation', 1888), “Karasu” (鴉; The Raven) translated by Motoki Sadao [元木貞雄; details unknown] (Nȳ nashonaru dai-go dokuhon chokuyaku (2 no ge); ニューナショナル第五読本直 訳 : 意解插入 (2ノ下); 'New National Fifth Reader: Direct Translation (Volume 2, part 2)’, 1891), “Tsutamomiji” (蔦紅 
葉; 'Scarlet Ivy'= The Murders in the Rue Morgue) ${ }^{17}$ by Enomoto Haryū [榎本破笠; 1866-1916] (Yamato shimbun, October 3-December 29, 1892), and “Kaigarasu” (怪鴉; lit. 'Supernatural Raven'=The Raven) translated by Isobe Yaichirō [磯辺弥一郎; 1861-1931] (Eibungaku kōgiroku (dai $4 \mathrm{kan}$ ); 英文学講義録 (第4巻); English Literature Studies: Lecture Transcripts (Volume 4)', 1893)—appeared either in newspapers as 'tsuzukimono' (lit: 'to be continued' stories ${ }^{18}$ ) or school text books. It was not until Uchida Rōan, an already established translator well-known for producing the first translation of Dostoyevsky's Crime and Punishment (Tsumi to batsu, 1892-1893), translated “The Black Cat” in 1893 in a style that closer resembled classical prose (compared with Aeba's more colloquial prose) that the first of Poe's translated works entered the realm of 'serious literature.' Following this translation, very few of Poe's works appear in book-form for the remainder of the Meiji era. Instead, literary magazines for a variety of target audiences flourish, and it is through these magazines that his works take on new meanings. Translations of The Black Cat appeared in magazines for English language study on two occasions in this period: Sakurai Ōson's “The Black Cat” in Eibun Shinshi: The Student in 1904, and Kita Tōichi's “The Black Cat: Kuroneko” in Eigo no Nippon: The Nippon in 1909 (Fig. 6).
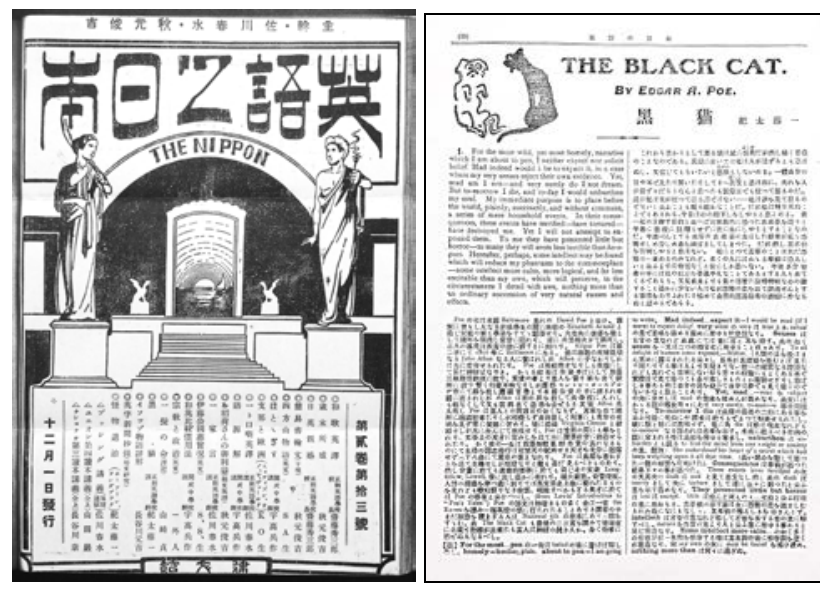

Fig. 6: “The Black Cat: Kuroneko” in Eigo no Nippon: The Nippon, 1909.

As the magazine titles suggest, the purpose of these publications was to introduce students to English literature, and often these magazines served to instruct students how to read English texts through the provision of parallel texts, word-for-word translations and grammar constructions in extensive footnoting. Deconstruction of Poe's language throughout the main body of the translated text provides sufficient evidence of a shift in purpose, resituating the intent of the original work as a gothic tale to English language study resource. Generic shifts are further revealed in the 'study notes', which explicate the scenes to come, removing suspense and literary effect from the intent of the original tale.

\footnotetext{
${ }^{17}$ An adaptation of The Murders in the Rue Morgue according to Kawato and Sakakibara (2011).

${ }^{18}$ A genre conceived through the advent of the newspaper in Meiji Japan. A consensus as to whether these stories were considered "literature" had yet to be established at this point in time.
}

The story begins with the narrator and protagonist of the tale penning his confession from a jail cell and awaiting execution for a crime that is not revealed to the reader until the climax at the very end. Both target texts, however, indicate earlier in the piece how the plot is about to unfold.

The first page of Poe's ST reads:

For the most wild, yet most homely, narrative which I am about to pen, I neither expect nor solicit belief. Mad indeed would I be to expect it, in a case where my very senses reject their own evidence. Yet, mad am I not - and very surely do I not dream. But to-morrow I die, and to-day I would unburthen my soul.

(Poe 2010, 207)

The 'study notes' to the corresponding section in TT1 (“The Black Cat: Kuroneko,” Eigo no Nippon: The Nippon ${ }^{19}$ ) reads:

“To-morrow I die" here refers to something that happens in the final two lines of this story. The reader must wait until the end to find out why he must die, so no explanation has been given here on purpose. In any case, "die" is the present state and "to-monow" (tomorrow) indicates the future. 20

(Kita 1909, 20) [20]

Further along in the story, after the protagonist develops an aversion to the recently adopted cat, the ST reads:

This dread was not exactly a dread of physical evil - and yet I should be at a loss how otherwise to define it. I am almost ashamed to own - yes, even in this felon's cell I am almost ashamed to own - that the terror and horror with which the animal inspired me had been heightened by one of the merest chimeras it would be possible to conceive.

(Poe 2010, 211)

Again, the study notes to the corresponding section in TT1 reveals:

"at a loss" = to be puzzed (puzzled). "otherwise” = in any other way. "it" refers to "this dread." "own" = confess, "tihs (this) felon's cell" refers to a section further on in the story where he kills his wife and he writes this because he is found to be the murderer and is imprisoned. ${ }^{21}$

(Kita 1909, 33) [21]

The corresponding section in the study notes of TT2 ("The

\footnotetext{
19 “The Black Cat: Kuroneko" was published over six editions of Eigo no Nippon: The Nippon, from June 1 (Vol.2, No.6) to December 1 (Vol.2, No.13), 1909.

$20 「$ To-morrow I die は此編の最後の二行にある事を伝ふ何故に死 ぬにや讀者は終りまでまつて解決せられたし、故に態と茲には説明せ ず、兔に角 die は形は現在なれども to-monow なる語あれは未来を示 す」

${ }^{21}$ Amendments in parentheses added by the author. Source Text as appears in the original (including typos): $\ulcorner\ldots$ at a loss=to be puzzed. otherwise=in any other way. it は「其の恐怖」。own=confess, tihs felon’s cell 此の悪人の獄とは今少し先に行くと妻を殺す處あり、其人殺が見 付かつて入獄して居る故かく伝ふ」
} 
Black Cat”, Eibun Shinshi: The Student ${ }^{22}$ ) similarly reads:

This prison (felon's cell). This person has killed his wife and is now imprisoned, awaiting the death penalty. ${ }^{23}$

(Sakurai 1904, 130) [22]

Despite the wife's murder not being revealed until later in the story, even a number of editions later in the case of Eibun Shinshi: The Student, ${ }^{24}$ the translator on both occasions extrapolates the protagonists' reason for the retelling of the story from his "felon's cell" in the student-oriented study notes well before the scene is played out.

\section{Grimms' Fairy Tales}

There are approximately 146 instances of Grimms' stories translated in the Meiji era. ${ }^{25}$ Interestingly, though, unlike Hamlet or The Black Cat which were translated multiple times, Shibue Tamotsu's Seiyō yōkai kidan is the only recorded translation to feature the tale "The Seven Swabians" in this period. Based on Shibue's explanation for his reinterpretation that saw the Swabians become 'feed for the kappa', it is possible that the lack of "kaidan-like elements" became an impediment on the popularity of the story. However, while the kappa in this particular tale might be deemed an interpretative aid for making sense of Western fairy tales (i.e. bringing them closer to the traditional Japanese kaidan), the kappa and other such supernatural creatures were also used during the Meiji period—and indeed even today—as a vehicle of parody and of metaphor. In 1868, for example, Fukuzawa Yukichi [福澤諭吉; 1835-1901] published a text entitled Kunmō: Kyūri zukai (訓蒙 窮理図解; 'Illustrated Explanations of Scientific Principles') that provided simple diagrams and explanations of various natural phenomena for use as a primary school science textbook (Fig. 7). Four years later in 1872, Kanagaki Robun published a parody of this work entitled, Kyūri zukai (full title: Kyūri zukai: Kappa sōden; 胡瓜遣 河童相伝; lit. The Cucumber-Bearer: The Kappa's Inheritance)—-the title itself a homonym of Fukuzawa's text. The homonymous connection carries through Kanagaki's text as can be observed in comparison of the contents pages of the respective titles (Fig. 8). Fukuzawa's text lists chapters that describe properties of unki (温気; heat) and küki (空気; atmosphere), whereas Kanagaki's satire adopts the ideographs unki (運気; luck) and kūki (食気; appetite). Kanagaki even goes on to explicitly state that the "resounding acclaim" for Fukuzawa's work is exaggerated and temporary, comparing it to the "fart of a kappa" (kappa no he; 河童の屁) : “Like a kappa’s fart, though it momentarily resounds within the water, it soon floats to the surface as a bubble and disappears” (Reitan 2009, 18) [23].

\footnotetext{
22 "The Black Cat" was published over seven editions of Eibun Shinshi: The Student, from July 1 (vol.2, No.1) to December 1 (Vol.2, No.11), 1904.

$23\ulcorner こ の$ 牢獄 (felon's cell). この人今は妻を殺して囚はれ、死刑を宣 告されてみる也。」

${ }^{24}$ In Vol.2, No.8, October 15, 1904.

${ }^{25}$ According to those listed in M, Kawato, Y. Noguchi, and T. Sakakibara, Nihon ni okeru gurimu dōwa honyaku shoshi, Tokyo: Nada shuppan senta, 2000 .
}

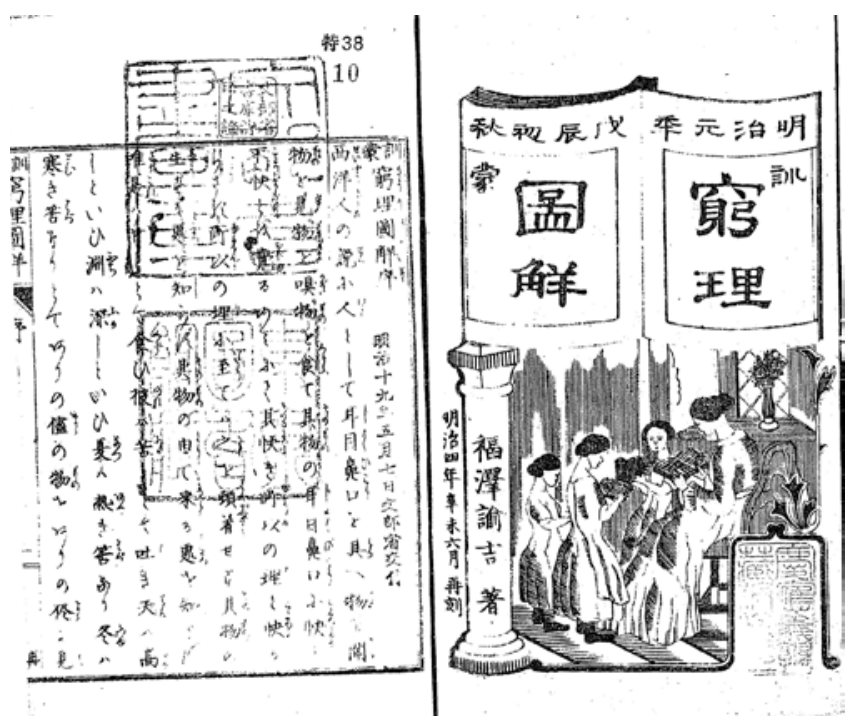

Fig. 7. Fukuzawa Yukichi’s Kyūri zukai (1871 version).

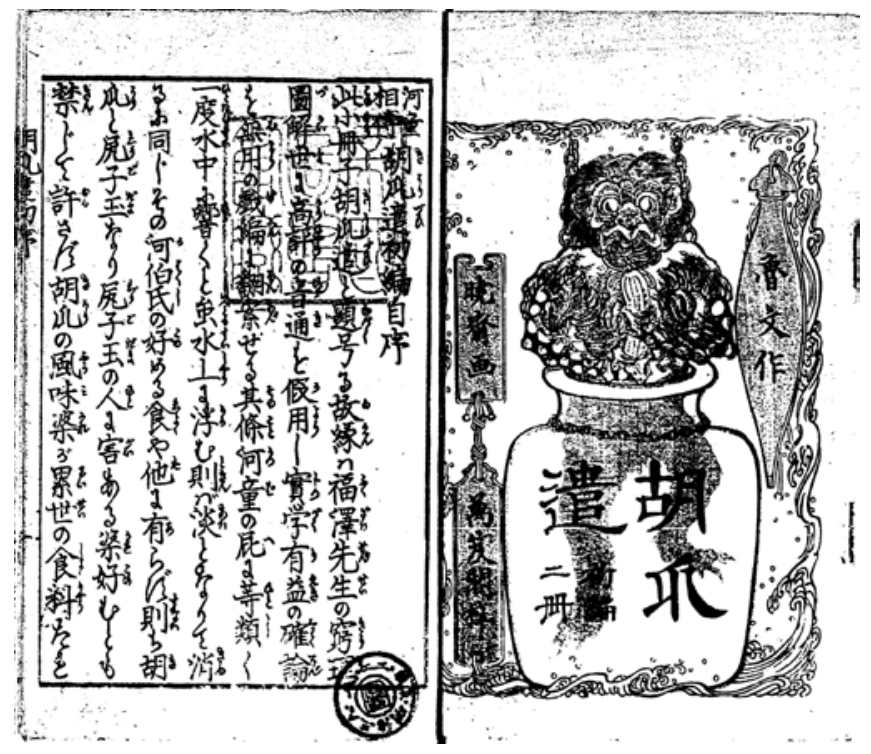

Fig. 8. Kanagaki Robun’s kappa parody Kyūri zukai (1872).

Furthermore, Sasayama Junichi [ 笹山準 — ; details unknown] also briefly takes up the kappa motif in his translation of The Autobiography of Benjamin Franklin (1771) as Shinyaku furankurin: Risshi seikō (新訳フランクリ

ン 立志成功; 'New Translation of Franklin: Life Goal Success') in 1910. Chapter 43 of Sasayama's translation (which corresponds to "Chapter 6: First Visit to London" in the ST) is entitled, “Kappa no geitō" (河童の芸当; lit. The Kappa's Tricks) (108-9) [24]. Although there is no further reference to 'kappa' in the text, he uses the term here as a metaphor for Benjamin Franklin's astounding swimming ability — evidently a rare and remarkable skill to the Japanese reader at this point in history.

Thus, while Grimms' fairytales were translated extensively throughout the Meiji period, appearing in a variety of literary avenues and publications for a variety of audiences that included both adults and children, what can also be observed here is the multi-functionality of the supernatural to reinterpret texts of multiple genres. If translation functioned as a contact zone that provided a means for Meiji Japan to intercept and absorb modernity, 
then the supernatural functioned too as a means to interpret and critique it. Through an analysis of its uses in historical context, the kappa, like the bakeneko and the kori, becomes a symbol that highlights the intricate relationship maintained between modern Japan (including scientific thought and translation) and traditional culture (the supernatural) in the Meiji era.

\section{The Murders in the Rue Morgue 26}

As with many translations of Western and European works in this era, Edgar Allan Poe's The Murders in the Rue Morgue appeared in multiple publications for multiple readerships. The first translation is accredited to Aeba Kōson as “Rū morugu no hitogoroshi” (ルーモルグの人殺し; The Murderer of the Rue Morgue), serialized in the Yomiuri Shimbun newspaper from December 14-30, 1887. The second translation (adaptation), "Tsutamomiji”, published over forty-seven installments in the Yamato Shimbun (やまと 新聞) newspaper from November 3 to December 29, 1892, resituated the original Rue Morgue (Paris) murders to “Building 92 of the Tsukuji foreign settlement quarters (築地 居留地第九十一番館) in Tokyo, Japan, where the murders of a foreign (non-Japanese) mother and her daughter are committed at the hands of a "hihi” (狒々; baboon). Osada Shūtō's "Shōjōkai” appeared in the literary magazine Bungei kurabu (文芸俱楽部; ‘Literature Club’) in October, 1899, and was translated again ten years later in 1909, appearing as an unfinished translation in the January edition of English study magazine Eigo seinen (英語青年; ‘English Language Youth’) as “Kōzetsu Sōzetsu Moruguchō no satsujin jiken” (凍絶愴絶 モルグ町の惨殺事件; lit. 'Bloody Tragedy: The Morgue Town Murder Case') by Fukazawa Yoshijirō [深沢由次郎; details unknown].

Osada's translation is unique amongst these four examples not only because of his decision to reposition the tale from detective fiction to Japanese-style kaidan as suggested in his preface (mentioned in Section II above) and his translation of the title as "Shōjōkai"—kai (怪) signifying the presence of strange or supernatural elements in the story-but also for his use of the term 'shōjō' and the duality of its interpretation in the Meiji context.

As stated previously, up until the introduction of Western knowledge in the Meiji era, shōjō were regarded as mythical, water-dwelling creatures that drank alcohol and spoke human language. Their stories were often told in kaidan tales and theatrical (kabuki and Noh) performances. Aeba Kōson's initial translation refers to the murderer in the tale as "a giant monkey called an orangutan” (oranguutan to iu özaru; オラ ングウタンといふ大猿) [25], which suggests that the actual animal was still relatively unknown to the general public at this point in time. As stated in the corresponding analysis in Section II, investigation reveals a number of publications

\footnotetext{
${ }^{26}$ This section appears in the article D.J. Wyatt, "Creatures of Myth and Modernity: Representations of Shōjō in the Meiji Era”, New Voices in Japanese Studies, Vol. 9, 2017, pp. 71-93.
}

prior to 1887 that explicate the term 'shōjō' as 'orangutan'-the characters for the original preternatural “shōjō” (i.e. 猩々) were applied to the real mammalian shōjō (orangutan) when imported through translations of zoological and scientific texts - thus differentiation between the two became one of context. In the case of Osada's "Shōjōkai," however, unfamiliarity of the modern-day shōjō is interpreted through a more familiar traditional understanding of the shōjō as a supernatural creature-that is, by resituating Poe's tale within the traditional kaidan genre-blurring the lines between past and present and further enhancing the possible readings of the tale.

The Murders in the Rue Morgue ends with the revelation that a man in Paris had recently imported a Bornean orangutan and that it had in fact escaped its enclosure and in a frightened state, on the loose in the city, accidently killed the two women in the Rue Morgue. Coincidentally, Ueno Zoo in Tokyo introduced an orangutan into its enclosure in 1898, only one year prior to the publication of Osada Shūtō's translation. Therefore, like the kori, bakeneko, kappa, and other creatures of traditional Japanese culture, the shōjō here functioned not only as a means to bring new Western texts closer to the Meiji public unfamiliar with foreign cultures - in this case, through the intertextual associations of the shōjō and its origins in traditional supernatural tales and folklore-but also as an aid in processing modernity, whether in the form of new literary genres like 'detective fiction,' of new branches of science and academic learning, or of new exotic creatures like the orangutan [26]. ${ }^{27}$

\section{SUMMARY}

As shapeshifters of the Meiji era, translated texts could be read as Japanese kaidan, Western gothic-horror, literary classic, popular literature, children's tale, English study companion, or any or all of the above combinations depending on the various contexts and publications through which they surfaced and circulated. Each reading of a single text creates new meaning suggesting the possibility of new intertextual connections to previous translations or to alternate texts entirely. And in this border-crossing of texts and meanings, genre itself may be seen as a product of systems that are susceptible to change. The continuous circulation of translations and frequent re-translations of texts like Hamlet or The Black Cat analyzed in this study demonstrates the transmutability of translation, particularly the multi-functionality ascribed to translated literature in Japan's Meiji era. The use of traditional (supernatural) motifs, like the kappa in Shibue Tamotsu's translation of Grimms' Fairy Tales, highlights one way in which unfamiliar content and new literary genres were processed and understood in this period, but as evidenced by further examples of kappa in this era, traditional knowledge not only provided a way of making texts more familiar to the Meiji reader, it also provided a way of explicating and understanding the remarkable abilities of modern-day individuals_-Benjamin Franklin's 'kappa-like' swimming skills_even a way to

\footnotetext{
${ }^{27}$ For a detailed analysis of the shōjō in Meiji Japan see D. J. Wyatt 2017, 71-93.
} 
subvert modern thought—Kanagaki Robun’s kappa parody of Fukuzawa Yukichi's textbook on modern science. Finally, Osada Shūtō's translation of Poe's The Murders in the Rue Morgue, a tale initially intended as a murder-mystery, represents a story which, through translation, has the ability to cross genres from detective fiction to Japanese kaidan. The situational circumstances surrounding Osada's translation (and indeed possibly the motive behind the translation) invites a new interpretation of Poe's orangutan escapee-one that gains from its intertextual associations with traditional tales, allowing for new contexts and readings of both the traditional alcohol-loving shōjō of folklore and the shōjō (orangutan) of modern Japan.

The interpretation of the supernatural in the Meiji period translation not only illuminated the ways in which ghosts and bakemono were localized to more closely resemble Japanese counterparts, but also demonstrated how modern knowledge and society were processed through systems of traditional culture.

Authors of native kaidan fiction in this era were confronted with the dilemma of adapting their stories to reflect modern knowledge (i.e. explaining supernatural elements with scientific logic_-such as the rationalizing of ghostly sightings as neurological illness) and following traditional narrative (i.e. accepting the supernatural as real); however, translators of gothic literature and supernatural tales often circumvented this conflict through intertextual creativity that reinterpreted these "new" foreign texts in a way that was more familiar to the Meiji reader, or otherwise through a generic shift that took the focus away from the content and themes to a focus on the (re)construction of the language by way of extensive footnoting and parallel texts. And it is through these such avenues that a text like "The Black Cat,” in the short span of 25 years in the Meiji period, from its first translation in 1887 to its final translation of the era in 1911, morphs from pseudo-Western kaidan, to 'faithful translation' and positioning as a literary classic, to English study, to children's tale, back to English study, back to classic work, and then finally to women's literature. Further study is needed to determine how each of the intended readerships of these translations impact on the individual readings, and how translations for specific readerships in this era bring different elements of the story and its overall (re)construction into focus.

\section{CONCLUSION}

Following the Meiji Restoration in 1868, foreign literature became a crucial medium for the dissemination of modern knowledge and Western thought imported through translation. Following this trend, translations of Western and European literature containing supernatural elements were borrowed, reproduced, and transformed to suit a multitude of contexts.

Supernatural elements, whether finally explained or not, constitute one of the axes of supernatural fiction and the gothic genre, and while the mystery and fear inherent in such tales are a literature that profits from these very themes, Meiji Japan profited from a multifaceted understanding of translation practices, reflecting not only an awareness of how a translated text should be, but how a translation could be (i.e. how texts can become relevant for different readerships).

This paper has presented a diachronic analysis of four supernaturally-themed texts translated into Japanese in the Meiji era. It has demonstrated the way in which the pursuit of Western knowledge, the study of the English language, public thought regarding the supernatural, and traditional culture influenced Meiji translation practices, giving rise to multiple translations that morphed and changed shape according to various arbitrary, ideological and/or pedagogical factors and specific readerships.

Like the kori, bakeneko, kappa, shōjō and myriad of other traditional folkloric creatures in Japan, translation in the Meiji era maintained a ubiquitous presence that reflected all the traits of a modern-day bakemono: a shapeshifter that could change roles easily as it changed form, appearing first in one genre then another. As 'bakemono,' Meiji translation eludes all efforts at simple categorization, leaping from register to register with contemptuous ease.

\section{REFERENCES}

[1] A. Takeishi, "Kōyagawa no kitsune, onna to henjite uma no shiri ni norukoto,” Konjaku Monogatari-shū <Honchō sezoku-hen> (ge): Zengendaigoyaku, Tokyo: Kōdansha, pp. 136-144, 2016.

[2] A. Takeishi, "Jijūden no taishiro no oomiakashi tori ni mono kitarukoto,” Konjaku Monogatari-shū <Honchō sezoku-hen> (ge): Zengendaigoyaku, Tokyo: Kōdansha, pp. 41-43, 2016.

[3] K. Komatsu, Nihon Yōkai Ibunroku, Tokyo: Shōgakukan, 1992.

[4] E. Sanyūtei, Shinkei Kasane ga Fuchi, Tokyo: Inoue Katsugorō, 1888.

[5] R. Kanagaki, "Hamuretto yamato nishikie,” in Meiji Honyaku Bungaku Zensh $\bar{u}<$ Shimbun zasshi-hen> 2: Sheikusupia-shū II, M. Kawato and T. Sakakibara, Eds. Tokyo: Ōzora, 1996, pp. 7-74.

[6] E. A. Poe, "The black cat," The Complete Tales and Poems of Edgar Allan Poe, New York: Race Point Publishing, pp. 207-213, 2014.

[7] T. Todorov, The Fantastic: A Structural Approach to a Literary Genre, R. Howard, Trans. Cleveland: Press of Case Western Reserve University, 1973.

[8] K. Aeba, "Seiyō kaidan kuroneko (jō)," Yomiuri Shimbun <Furoku>, November 3, 1887.

[9] J. Momokawa, Takayagura Rikishi Kyūmyōden <Gekan>, Tokyo: Kakuseisha, 1885.

[10] J. Stephens, Language and Ideology in Children's Fiction, London: Longman, 1992.

[11] J. Grimm and W. Grimm. (March 10, 2017). The seven swabians. Household Tales by Brothers Grimm. [Online]. Available: https://ebooks.adelaide.edu.au/g/grimm/g86h/chapter119.html

[12] M. Kawato, Y. Noguchi, and T. Sakakibara, Nihon ni Okeru Gurimu Dōwa Honyaku Shoshi, Tokyo: Nada Shuppan Sentā, pp. 132-133, 2000.

[13] H. Nishiguchi, "Shibue tamotsu yaku Seiyō yōkai kidan no sashie to kontei ni tsuite: Sashie kara mita meijiki gurimu dōwa honyaku," Senshū Jinbun Ronshū, pp. 143-164, March 2013.

[14] T. Shibue, “Shichimei no Sūebiajin,” Seiyō Yōkai Kidan: Shōgaku kōwa zairyō, Tokyo: Hakubunkan, pp. 247-252, 1891.

[15] S. Osada, “Shōjōkai,” Bungei kurabu, vol. 5, no. 13, pp. 118-136, 1899.

[16] R. Terajima, Wakan Sansai zue (Chūnomaki), Osaka: Chūkindō, 1888.

[17] M. Baker, In Other Words: A Coursebook on Translation, London: Routledge, 1992.

[18] M. Kawato and T. Sakakibara, Meiji Honyaku Bungaku Zenshū <Shimbun Zasshi-hen> 2: Sheikusupia-shū II, Tokyo: Ōzora, 1996.

[19] M. Kawato and T. Sakakibara, Sekai Bungaku Sōgō Mokuroku <Dai 4 maki: Amerika-hen>, Tokyo: Ōzora, 2011.

[20] T. Kita, “The black cat: Kuroneko,” Eigo no Nippon: The Nippon, vol. 2, no. 6, p. 20, 1909.

[21] T. Kita, “The black cat: Kuroneko,” Eigo no Nippon: The Nippon, vol. 2, no. 12, pp. 32-35, 1909.

[22] O. Sakurai, “The black cat,” Eibun Shinshi: The Student, vol. 2, no. 5, pp. 129-130, 1904.

[23] R. M. Reitan, Making a Moral Society: Ethics and the State in Meiji Japan, Honolulu: University of Hawai'i Press, 2009. 
[24] J. Sasayama, Shinyaku Furankurin: Risshi Seikō, Tokyo: Seikadō, 1910.

[25] K. Aeba, "Rū morugu no hitogoroshi”, Yomiuri Shimbun <Furoku>, December 14-30, 1887.

[26] D. J. Wyatt, "Creatures of myth and modernity: Representations of Shōjō in the Meiji Era," New Voices in Japanese Studies, vol. 9, pp. 71-93, 2017.

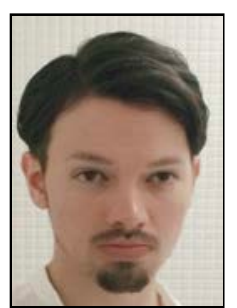

Daniel $\mathbf{J}$. Wyatt is a Japanese society and cultural studies PhD candidate at Kyushu University, Japan. He got the bachelor degree of arts in Japanese at James Cook University, Cairns, Australia in 2008, master degree of interpreting and translation studies at Monash University, Melbourne, Australia in 2009, doctor degree of social and cultural studies at Kyushu University, Fukuoka, Japan (tbc).
His doctoral dissertation investigates the development of translation practices of foreign literature in Meiji era Japan in relation to discourses of the supernatural. His current researches include the reception and transcreation of gothic literature, native folklore and supernatural tales, production and transition of knowledge, and translation studies in Japan with a focus on the Meiji era. 